Open Access

\title{
The effect of nighttime trading of futures markets on information flows: evidence from China
}

\author{
Hung-Gay Fung ${ }^{1 *}$, Liuqing Mai ${ }^{2}$ and Lin Zhao ${ }^{3}$
}

\author{
* Correspondence: \\ fungh@msx.umsl.edu \\ ${ }^{1}$ College of Business Administration \\ \& Office of International Services \\ and Program, University of \\ Missouri-St. Louis, One University \\ Blvd, St. Louis, MO 63121, USA \\ Full list of author information is \\ available at the end of the article
}

\begin{abstract}
Background: In the past couple of years, China's futures exchanges have launched nighttime trading sessions.

Methods: We use daily data from 23 commodity futures to investigate the impact of this important policy change.

Results: Our findings suggest that the launching of nighttime trading effectively improved the efficiency of futures prices and reduced the volatility of prices. The normality of returns improves during the post-nighttime trading period. As documented in the literature, the interactions between trading activities (i.e., trading volume and open interest) and volatility conform better to the observed patterns in developed markets.
\end{abstract}

Conclusions: This study provides sound evidence that China has taken steady steps toward its goal of establishing price-setting power in key commodities on world financial markets.

Keywords: China's futures market, Futures price and volatility, Nighttime trading JEL codes: G13, G14, G15

\section{Background}

Over the past two decades, China's futures market began their stunning development and rapid expansion. China currently has three commodity futures exchanges: the Shanghai Futures Exchange (SHFE), the Dalian Commodity Exchange (DCE), and the Zhengzhou Commodity Exchange (ZCE). The main trading venue for financial futures, the China Financial Futures Exchange (CFFEX), was established in 2006 in Shanghai. China is now among the world's leading commodity futures markets. For example, in 2014, China's futures in rapeseed meal, soybean meal, white sugar, rubber, and palm oil were the world's top five most actively traded agricultural futures; futures trading in coke and coking coal on the DCE rank fourth and fifth among energy futures, respectively. ${ }^{1}$ The rapid growth of China's futures market has attracted great attention.

China has actively been seeking ways to further liberalize its capital market and promote the internationalization of its futures markets. For example, the Qualified Foreign Institutional Investors (QFI) program launched in 2002 and the Renminbi Qualified Foreign Institutional Investors (RQFII) scheme introduced in 2011 provide venues for 
foreign institutional investors with certain characteristics to participate in China's securities market. The recent launching of nighttime trading hours is a major step by China on its way to strengthening the price-setting power of key commodities on the global financial market. Nighttime trading of gold and silver futures on the SHFE was launched in July 2013, and thereafter, the other two commodity exchanges in China, the DCE and the ZCE, followed its example. By the end of 2015, many commodity futures on China's exchanges had an additional trading session at night, while trading in markets overseas (i.e., the USA, Europe) is active. Kyle (1985) modeled a framework that incorporates information into the price across time with trading behavior. Thanks to the nighttime trading sessions, traders in China are able to better manage their risk and react to the information flows released from other markets more swiftly through prompt trading. The futures price in China's market is thus expected to be more efficient because of this change.

Prior studies have explored the information transmission mechanism across markets in different geographic locations as well as the price linkages between futures market and the corresponding spot market (e.g., Eun and Shim 1989; Fung et al. 2001; Ghosh et al. 1999; Xu and Fung 2005). Trading activities in futures markets and their interactions with pricing dynamics have also been examined in the literature (i.e., Bessembinder and Seguin 1992, 1993; Fung and Patterson 2001; Kao and Fung 2012; Pliska and Shalen 1991).

This study investigates the impact of additional trading hours at night on the dynamics of China's futures market. Our goal is to examine whether more information has been incorporated into futures prices after the policy change and prices are better behaved according to the results in developed country markets. To this end, we have taken several steps. First, we examine the statistics of futures returns, including the mean, variance, skewness, and kurtosis during the pre- and post-nighttime trading periods. We aim to examine how these moments change after nighttime trading. If new information is incorporated into the futures prices, we would expect the return distribution of the futures contracts to be more symmetric to reflect the even flow of information.

In addition, we test two hypotheses related to changes in volatility behavior after the launching of nighttime trading on volume (a proxy for information) and open interest (a proxy for market depth). A large number of studies have documented a positive relationship between return volatility and volume (Karpoff 1987), which suggests three related hypotheses. The mixture-of-distribution hypothesis (MDH) relates trading volume to the number of new information arrivals (e.g., Clark 1973; Epps \& Epps 1976; Tauchen \& Pitt 1983). The sequential-arrival-of-information hypothesis (SAIH) indicates that traders receive information at different times. That is, the volatility is potentially predictable with knowledge of trading volume (e.g., Foster 1995; Wang \& Yau 2000). Finally, the asymmetrical information hypothesis argues that informed traders cluster on one side of a market to reduce price volatility (e.g., Daigler \& Wiley 1999; Downing \& Zhang 2004). These three theories suggest that if new information is incorporated into futures prices after post-nighttime trading, we should expect to find a stronger positive relationship between volume and volatility.

We also examine the relationship between volatility and market depth. Kyle (1985) in his theoretical model suggests that a deep market lowers price pressures to reflect new 
information, implying less volatility. Similarly, Kim and Verrecchia (1994) argued that a shallow market can increase the difficulty for large trades to occur smoothly and may reduce the speed of information transmission, thus causing greater volatility. To support these theoretical results, Bessembinder and Seguin $(1992,1993)$ and Fung and Patterson (2001), in their analysis of futures contracts, documented a negative relationship between price volatility and market depth. The overall findings from these studies suggest that market depth and volatility have an inverse relationship. If market depth shows improvement after the post-nighttime trading in Chinese futures markets, we should expect that the negative coefficient between the volatility and market depth will be stronger in post-nighttime trading.

We find empirical evidence of enhanced efficiency in futures prices and show that the volatility behavior exhibits improvement with volume and market depth after the launching of nighttime trading. This study contributes to the literature with empirical evidence about the effectiveness of the new trading policy. Our findings also provide practitioners with important information about trading futures in China and provide other developing countries with lessons for improving trading on their futures markets.

The rest of the paper is organized as follows. The "Data" section presents the data. The "Methods" section explains the methodology. The "Results and discussion" discusses the empirical results of our regression analysis. The final section presents a summary and concludes the paper.

\section{Data}

Futures exchanges in China started to launch nighttime trading sessions in July 2013. At the end of 2015, 28 commodity futures with nighttime trading hours, including gold, silver, copper cathode, aluminum, zinc, lead, steel rebar, natural rubber, bitumen, hot rolled coils, nickel, and tin on the SHFE; RBD palm olein, metallurgical coke, no. 1 soybeans, no. 2 soybeans, soybean meal, crude soybean oil, coking coal, and iron ore on the DCE; and white sugar, pure terephthalic acid (PTA), no. 1 cotton, rapeseed meal, methanol, rapeseed oil, flat glass, and thermal coal on the ZCE.

Because of their additional trading hours at night, the futures market is accessible to domestic traders while markets overseas are still open; hence, the information flow is expected to be incorporated into domestic futures prices in a more timely fashion through trading activities. This study investigates the impact of the launching of nighttime trading in China's futures market on its domestic market dynamics using daily futures data from the Commodity Systems Inc. (CSI) database. The sample information is summarized in Table 1 . Of the 28 commodity futures listed, the 23 futures with a longer trading history and data available in the CSI database during the pre-change period are included in our sample. ${ }^{2}$ The sample spans the earliest available date of each selected future in the CSI database until the end of October 2015. We generate continuous futures price time series by rolling over to the next nearby contract when its open interest is larger.

The summary statistics of futures returns during the period before and after the launching of nighttime trading are shown in Tables 2,3 , and 4. The futures return $\left(R_{t}\right)$ is constructed as the $\log$ difference of daily settlement prices (i. e., $\left.R_{t}=\log \left(P_{t}\right)-\log \left(P_{t-1}\right)\right)$. The statistics for futures on each of the three commodity exchanges are presented in separate panels. Several points are worth noting. First, the mean returns of most futures remain 
Table 1 Selected China's futures with nighttime trading hours

\begin{tabular}{|c|c|c|c|c|}
\hline Product (ticker symbol) & Exchange & Nighttime trading hours & Launching of nighttime trading & Start of sample \\
\hline Gold (AU) & SHFE & $21: 00-2: 30$ & $7 / 5 / 2013$ & $1 / 17 / 2008$ \\
\hline Silver (AG) & SHFE & $21: 00-2: 30$ & $7 / 5 / 2013$ & $12 / 31 / 2012$ \\
\hline Copper cathode (CU) & SHFE & 21:00-1:00 & $12 / 20 / 2013$ & $12 / 11 / 2003$ \\
\hline Aluminum (AL) & SHFE & 21:00-1:00 & $12 / 20 / 2013$ & $12 / 11 / 2003$ \\
\hline Zinc (ZN) & SHFE & $21: 00-1: 00$ & $12 / 20 / 2013$ & $4 / 12 / 2007$ \\
\hline Lead (PB) & SHFE & 21:00-1:00 & $12 / 20 / 2013$ & $3 / 24 / 2011$ \\
\hline Steel rebar (RB) & SHFE & 21:00-1:00 & $12 / 26 / 2014$ & $3 / 27 / 2009$ \\
\hline Natural rubber (RU) & SHFE & 21:00-23:00 & $12 / 26 / 2014$ & $12 / 11 / 2003$ \\
\hline RBD palm olein $(P)$ & DCE & $21: 00-23: 30$ & $7 / 4 / 2014$ & $5 / 19 / 2008$ \\
\hline Metallurgical coke $(J)$ & DCE & $21: 00-23: 30$ & $7 / 4 / 2014$ & $4 / 28 / 2011$ \\
\hline No. 1 soybeans $(A)$ & DCE & $21: 00-23: 30$ & $12 / 26 / 2014$ & $12 / 11 / 2003$ \\
\hline Soybean meal (M) & DCE & $21: 00-23: 30$ & $12 / 26 / 2014$ & $12 / 11 / 2003$ \\
\hline Crude soybean oil $(Y)$ & DCE & $21: 00-23: 30$ & $12 / 26 / 2014$ & $5 / 19 / 2008$ \\
\hline Coking coal (JM) & DCE & $21: 00-23: 30$ & $12 / 26 / 2014$ & $8 / 14 / 2013$ \\
\hline Iron ore (I) & DCE & $21: 00-23: 30$ & $12 / 26 / 2014$ & $10 / 18 / 2013$ \\
\hline White sugar (SR) & ZCE & $21: 00-23: 30$ & $12 / 12 / 2014$ & $9 / 17 / 2008$ \\
\hline PTA (TA) & ZCE & $21: 00-23: 30$ & $12 / 12 / 2014$ & $9 / 17 / 2008$ \\
\hline No. 1 cotton (CF) & ZCE & $21: 00-23: 30$ & $12 / 12 / 2014$ & $6 / 1 / 2004$ \\
\hline Rapeseed meal (RM) & ZCE & $21: 00-23: 30$ & $12 / 12 / 2014$ & $12 / 28 / 2012$ \\
\hline Methanol (ME) & ZCE & 21:00-23:30 & $12 / 12 / 2014$ & $12 / 31 / 2012$ \\
\hline Rapeseed oil (OI) & ZCE & $21: 00-23: 30$ & $6 / 11 / 2015$ & $9 / 17 / 2008$ \\
\hline Flat glass (FG) & ZCE & $21: 00-23: 30$ & $6 / 11 / 2015$ & $2 / 28 / 2013$ \\
\hline Thermal coal (TC) & ZCE & $21: 00-23: 30$ & $6 / 11 / 2015$ & $3 / 7 / 2013$ \\
\hline
\end{tabular}

Sources: Shanghai Futures Exchange (SHFE), Dalian Commodity Exchange (DCE), Zhengzhou Commodity Exchange (ZCE)

relatively unaffected by the launching of nighttime trading. For 18 of the 23 sample futures, no statistically significant change in mean return is observed, except for silver, copper cathode, steel rebar, no. 1 soybeans, and thermal coal futures.

Second, most sample futures exhibit reduced variances after the nighttime trading was launched. Specifically, variances for metal futures on the SHFE, agricultural futures and energy futures on the DCE, and agricultural futures on the ZCE become significantly lower.

Third, changes in the skewness and kurtosis statistics reveal improvement toward the normality of return distribution during the post-nighttime trading period. In particular, negative skewness was eliminated and became insignificant for 14 of the 23 futures, indicating that downside risk was largely reduced when traders could access the futures market at night. Furthermore, significant excess kurtosis no longer exists for rapeseed meal futures and flat glass futures. The normal distribution hypothesis was rejected for all the sample futures during the pre-nighttime trading period, according to the Jarque-Bera test. ${ }^{3}$ After the launching of a nighttime trading session, three commodity futures-natural rubber, rapeseed meal, and flat glass-were found to have normally distributed returns.

The overall implication of overnight trading is that the returns of futures contracts became more symmetric, showing that balanced information is reflected in the prices on the market. 
Table 2 Summary statistics (Shanghai Futures Exchange)

\begin{tabular}{|c|c|c|c|c|c|c|c|}
\hline Futures & Sample period ${ }^{a}$ & Mean & Std. & Skewness & Kurtosis & Eq. mean ${ }^{b}$ & Eq. var. $^{c}$ \\
\hline \multirow[t]{2}{*}{ Gold } & Pre-NT & 0.00006 & 0.0131 & $-0.495^{* * *}$ & $3.948^{* * *}$ & 0.40 & $2.65^{* * *}$ \\
\hline & Post-NT & -0.00014 & 0.0080 & 0.141 & $1.336^{* * *}$ & & \\
\hline \multirow[t]{2}{*}{ Silver } & Pre-NT & -0.00438 & 0.0196 & $-1.138^{* * *}$ & $4.524^{* * *}$ & $-2.19^{* *}$ & $2.59^{* * *}$ \\
\hline & Post-NT & -0.00025 & 0.0122 & -0.016 & $2.487^{* * *}$ & & \\
\hline \multirow[t]{2}{*}{ Copper cathode } & Pre-NT & 0.00059 & 0.0159 & $-0.256^{* * *}$ & $1.432^{* * *}$ & $1.65^{*}$ & $2.77^{* * *}$ \\
\hline & Post-NT & -0.00034 & 0.0095 & $-0.407^{* * *}$ & $4.222^{* * *}$ & & \\
\hline \multirow[t]{2}{*}{ Aluminum } & Pre-NT & -0.00024 & 0.0097 & $-0.608^{* * *}$ & $4.562^{* * *}$ & 1.30 & $3.04^{* * *}$ \\
\hline & Post-NT & -0.00068 & 0.0056 & 0.058 & $1.078^{* * *}$ & & \\
\hline \multirow[t]{2}{*}{ Zinc } & Pre-NT & -0.00081 & 0.0156 & $-0.409^{* * *}$ & $1.675^{* * *}$ & -1.09 & $3.49^{* * *}$ \\
\hline & Post-NT & -0.00019 & 0.0083 & $-0.343^{* * *}$ & $2.881^{* * *}$ & & \\
\hline \multirow[t]{2}{*}{ Lead } & Pre-NT & -0.00053 & 0.0090 & $-0.500^{* * *}$ & $6.794^{* * *}$ & -0.50 & $1.34^{* * *}$ \\
\hline & Post-NT & -0.00028 & 0.0078 & -0.093 & $3.540^{* * *}$ & & \\
\hline \multirow[t]{2}{*}{ Steel rebar } & Pre-NT & -0.00059 & 0.0087 & -0.038 & $3.798^{* * *}$ & $1.78^{*}$ & $1.29^{* *}$ \\
\hline & Post-NT & -0.00190 & 0.0099 & -0.195 & $1.916^{* * *}$ & & \\
\hline \multirow[t]{2}{*}{ Natural rubber } & Pre-NT & -0.00022 & 0.0158 & $-0.276^{* * *}$ & $1.321^{* * *}$ & 0.67 & 1.09 \\
\hline & Post-NT & -0.00099 & 0.0152 & 0.025 & $0.582^{*}$ & & \\
\hline
\end{tabular}

***,**, and * denote significance at $1 \%, 5 \%$, and $10 \%$ levels, respectively

a"Pre-NT" represents the sample period prior to the launching of nighttime trading; "Post-NT" represents the sample period after the launching of nighttime trading

${ }^{\mathrm{b}}$ This column displays the $t$-value from the mean equality test

'This column displays the $F$-value from the variance equality test

In Fig. 1, we plot the mean returns and standard deviation (a proxy of risk) of these futures during the pre- and post-nighttime trading sub-sample period to examine the change in the risk-return relationship. We observed that the scatterplot has moved leftward and that the linear trend line is no longer negative after the launching of nighttime trading. The plot shows an obvious improvement in the risk-return relationship

Table 3 Summary Statistics (Dalian Commodity Exchange)

\begin{tabular}{llllllll}
\hline Futures & Sample period & Mean & Std. & Skewness & Kurtosis & Eq. mean & Eq. var. \\
\hline RBD palm olein & Pre-NT & -0.00067 & 0.0137 & $-0.468^{* * *}$ & $2.219^{* * *}$ & 0.37 & $1.85^{* * *}$ \\
& Post-NT & -0.00091 & 0.0101 & -0.054 & $1.272^{* * *}$ & & \\
Metallurgical coke & Pre-NT & -0.00148 & 0.0108 & $-0.247^{* * *}$ & $1.694^{* * *}$ & -0.13 & $1.97^{* * *}$ \\
& Post-NT & -0.00141 & 0.0077 & 0.014 & $1.226^{* * *}$ & & \\
No. 1 soybeans & Pre-NT & 0.00013 & 0.0103 & $-0.348^{* * *}$ & $3.541^{* * *}$ & $1.71^{*}$ & $1.67^{* * *}$ \\
& Post-NT & -0.00089 & 0.0080 & 0.193 & $3.287^{* * *}$ & & \\
Soybean meal & Pre-NT & 0.00024 & 0.0122 & $-0.211^{* * *}$ & $1.888^{* * *}$ & 1.13 & $1.79^{* * *}$ \\
& Post-NT & -0.00053 & 0.0091 & 0.229 & $1.221^{* * *}$ & & \\
Crude soybean oil & Pre-NT & -0.00054 & 0.0122 & $-0.557^{* * *}$ & $2.862^{* * *}$ & -0.50 & $1.85^{* * *}$ \\
& Post-NT & -0.00020 & 0.0090 & 0.048 & $0.998^{* * *}$ & & \\
Coking coal & Pre-NT & -0.00175 & 0.0104 & $-0.391^{* * *}$ & $0.917^{* * *}$ & -0.89 & $1.41^{* * *}$ \\
& Post-NT & -0.00101 & 0.0088 & -0.172 & $1.340^{* * *}$ & & \\
Iron ore & Pre-NT & -0.00208 & 0.0117 & $-0.332^{* *}$ & $1.497^{* * *}$ & -0.95 & $1.95^{* * *}$ \\
& Post-NT & -0.00081 & 0.0163 & -0.262 & $1.497^{* * *}$ & & \\
\hline
\end{tabular}

$* * *,{ }^{* *}$ and ${ }^{*}$ denote significance at $1 \%, 5 \%$, and $10 \%$ level, respectively 
Table 4 Summary Statistics (Zhengzhou Commodity Exchange)

\begin{tabular}{llllllll}
\hline Futures & Sample period & Mean & Std. & Skewness & Kurtosis & Eq. mean & Eq. var. \\
\hline White sugar & Pre-NT & 0.00007 & 0.0103 & $-0.127^{* *}$ & $2.930^{* * *}$ & -0.66 & $1.21^{*}$ \\
& Post-NT & 0.00056 & 0.0094 & -0.222 & $0.929^{* * *}$ & & \\
PTA & Pre-NT & -0.00020 & 0.0127 & $-0.275^{* * *}$ & $2.599^{* * *}$ & 0.43 & 1.17 \\
\multirow{2}{*}{ No. 1 cotton } & Post-NT & -0.00060 & 0.0137 & $-0.428^{* *}$ & $2.498^{* * *}$ & & \\
& Pre-NT & -0.00018 & 0.0093 & $-0.194^{* * *}$ & $7.749^{* * *}$ & 1.09 & $2.34^{* * *}$ \\
\multirow{2}{*}{ Rapeseed meal } & Post-NT & -0.00068 & 0.0061 & $-0.629^{* * *}$ & $3.093^{* * *}$ & & \\
& Pre-NT & 0.00056 & 0.0103 & -0.027 & $1.061^{* * *}$ & 1.04 & 1.06 \\
Methanol & Post-NT & -0.00034 & 0.0106 & 0.120 & 0.247 & & \\
& Pre-NT & -0.00026 & 0.0096 & 0.129 & $3.273^{* * *}$ & 0.67 & $2.25^{* * *}$ \\
Rapeseed oil & Post-NT & -0.00099 & 0.0144 & $-0.836^{* * *}$ & $2.766^{* * *}$ & & \\
& Pre-NT & -0.00022 & 0.0109 & $-0.169^{* * *}$ & $8.676^{* * *}$ & 0.58 & $1.75^{* * *}$ \\
& Post-NT & -0.00074 & 0.0082 & -0.180 & $3.215^{* * *}$ & & \\
Flat glass & Pre-NT & -0.00056 & 0.0095 & -0.042 & $0.539^{* *}$ & 0.27 & 1.13 \\
& Post-NT & -0.00085 & 0.0101 & -0.056 & 0.716 & & \\
Thermal coal & Pre-NT & -0.00093 & 0.0071 & -0.263 & $2.721^{* * *}$ & $2.14^{* *}$ & 1.13 \\
& Post-NT & -0.00297 & 0.0076 & $-0.628^{* *}$ & $2.189^{* * *}$ & & \\
\hline
\end{tabular}

***, ** and * denote significance at $1 \%, 5 \%$, and $10 \%$ level, respectively

for sample commodity futures, indicating that overnight trading contributes to improved information flows in the futures prices.

\section{Methods}

Prior studies suggested that returns volatility typically is positively related with trading volume, while its relationship with open interest should be negative (e.g., Admati \& Pfleidere 1988; Bessembinder \& Seguin 1992, 1993). The launching of nighttime trading hours is expected to enhance the swift transmission of information flows and improve the overall efficiency of futures prices. As a result, the volatility behavior of these future prices is expected to change accordingly during the post-nighttime trading period. We test this hypothesis by examining whether the relationship between volatility and

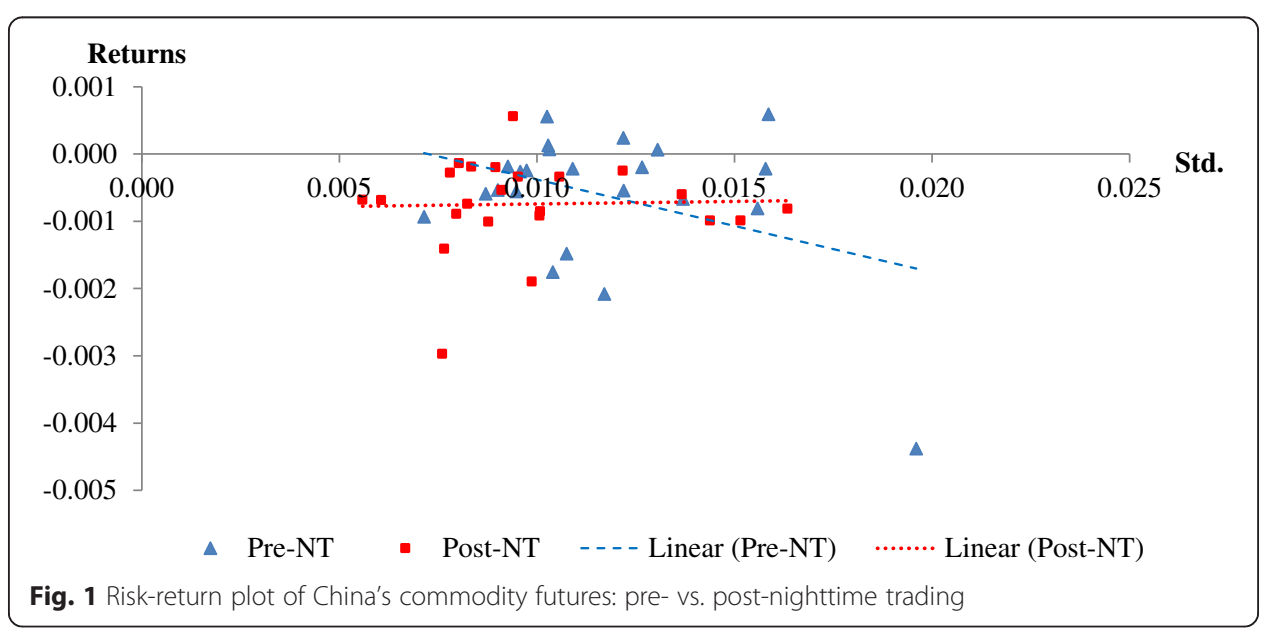


trading volume, as well as between volatility and open interest, changed significantly after the implementation of nighttime trading sessions.

Following the method in Schwert (1990) and Jones et al. (1994), our test consists of a two-step procedure. In the first step, we generate return volatility by regressing daily returns on its own autoregressive terms with the day-of-the-week effect controlled:

$$
R_{i t}=\sum_{k=1}^{5} \alpha_{i k} \mathrm{DAY}_{k t}+\sum_{j=1}^{10} \beta_{j} R_{i, t-j}+\varepsilon_{i t}
$$

where $\mathrm{DAY}_{k t}$ is the weekday dummy variable. The absolute value of residuals $\varepsilon_{i t}$ from this regression is then used as the proxy for return volatility.

In the second step, we use the following regression to investigate the volatility behavior of each futures return during the sub-sample periods before and after the launching of nighttime trading:

$$
\left|\varepsilon_{i t}\right|=\beta_{0 i}+\beta_{1 i} \mathrm{MON}_{t}+\beta_{2 i} \operatorname{DVOM}_{i t}+\beta_{3 i} D I_{i t}+\sum_{j=1}^{10} \rho_{i j}\left|\varepsilon_{i, t-j}\right|+\epsilon_{i t}
$$

where the dummy variable for Mondays $\mathrm{MON}_{t}$ equals $1, \mathrm{DVOM}_{i t}$ is the detrended trading volume, and $\mathrm{DOI}_{i t}$ is detrended open interest. In particular, $\mathrm{DVOM}_{i t}$ and $\mathrm{DOI}_{i t}$ are generated with the following 10-day backward moving average:

$$
\begin{aligned}
& \operatorname{DVOM}_{t}=\frac{\operatorname{LVOM}_{t}}{\left(\sum_{i=1}^{10} \mathrm{LVOM}_{t-i}\right) / 10} \\
& \mathrm{DOI}_{t}=\frac{\mathrm{LOI}_{t}}{\left(\sum_{i=1}^{10} \mathrm{LOI}_{t-i}\right) / 10}
\end{aligned}
$$

where $\mathrm{LVOM}_{t}$ and $\mathrm{LOI}_{t}$ represent the $\log$ form of the trading volume and open interest, respectively.

Equation (2) is estimated with Newey-West heteroskedasticity- and autocorrelationconsistent covariances. To further explore whether the estimated coefficients $\beta_{2 i}$ and $\beta_{3 i}$ in Eq. (2) differ significantly during the two sub-samples, we include an interaction dummy variable and estimate the full sample using the following equation:

$$
\begin{aligned}
\left|\varepsilon_{i t}\right| & =\beta_{0 i}+\beta_{1 i} M N_{t}+\beta_{2 i} D V O M_{i t}+\beta_{3 i}\left(\mathrm{NT}_{t} \times \mathrm{DVOM}_{i t}\right)+\beta_{4 i} \mathrm{DOI}_{i t} \\
& +\beta_{5 i}\left(\mathrm{NT}_{t} \times \mathrm{DOI}_{i t}\right)+\sum_{j=1}^{10} \rho_{i j}\left|\varepsilon_{i, t-j}\right|+\epsilon_{i t}
\end{aligned}
$$

where the nighttime trading dummy $\mathrm{NT}_{t}$ equals 1 for the time period after the launching of nighttime trading and 0 otherwise. The estimated coefficients $\beta_{3 i}$ and $\beta_{5 i}$ reveal whether there is significant change in the relationship between volume (open interest) and volatility after the implementation of nighttime trading sessions. Again, Eq. (3) is estimated using the Newey-West heteroskedasticity- and autocorrelation-consistent covariance matrix approach.

\section{Results and discussion}

We first examine the behavior of return volatility during the pre- and post-launching of nighttime trading sub-sample periods. The estimation results of Eq. (2) are shown in 
Tables 5, 6, and 7. During the pre-nighttime trading period, several futures, such as copper cathode, natural rubber, and RBD palm olein, are negatively related with volume and volatility. After the launching of nighttime trading, all three negative signs of the estimated coefficients become positive, indicating that a more liquid market is more volatile, which is consistent with the documented pattern in the literature. Similarly, the open interest of aluminum, zinc, natural rubber, and RBD palm olein are positively related with volatility. After the launching of nighttime trading, these coefficients become negative or insignificant, and these changes are more consistent with previous findings that having a deeper market tends to reduce volatility. The estimation results also show that the number of significant autoregressive volatility terms largely dropped during the post-nighttime trading sub-sample period, indicating a lower level of volatility clustering. Another interesting finding from the sub-sample analysis is that the volatility of most futures is subject to a significantly positive Monday effect, while such a relationship barely exists after the launching of nighttime trading.

Results in Tables 5, 6, and 7 indicate that, during the post-nighttime trading period, the volatility behavior of sample futures experienced significant changes in multiple aspects, including the autoregressive feature of volatility, the impact of weekdays, and, most importantly, the interactions between volatility and trading activities. To further explore the economic significance and magnitude in the changes of volume-volatility and open interest-volatility interactions, we estimate Eq. (3), where a time period dummy interaction term is specified. The estimation results of Eq. (3) are summarized in Tables 8, 9, and 10.

Tables 8,9 , and 10 show that the changes in the relationship between price volatility and trading volume (open interest) are explained by the estimated coefficients of the two interaction terms, $\mathrm{NT}_{t} \times \mathrm{DVOM}_{i t}$ and $\mathrm{NT}_{t} \times \mathrm{DOI}_{i t}$. For example, the volatilitytrading volume relationship of copper futures is more positive after the launching of nighttime trading (i.e., $\hat{\beta}_{3 i}=0.1572$ ), while the relationship between volatility and open interest becomes more negative (i.e., $\hat{\beta}_{5 i}=-0.1585$ ). Similar findings apply to many other futures, including zinc, lead, natural rubber, RBD palm olein, metallurgical coke, no. 1 soybeans, soybean meal, crude soybean oil, PTA, no. 1 cotton, and methanol.

Overall, the regression results suggest that the implementation of nighttime trading sessions by China's futures exchanges significantly improved the volatility behavior of the sample commodity futures. Such improvements are shown in aspects such as the reduced level of autocorrelation and the elimination of the Monday anomaly. Most importantly, the interactions between trading volume and volatility, as well as those between open interest and volatility, have moved toward the patterns observed in the derivative markets in developed countries; therefore, the change is more consistent with the implications of financial microstructure theories. That said, during the postnighttime trading period, the return volatility in these sample Chinese commodity futures tends to be higher when the market is more liquid (i.e., larger trading volume) and is mitigated in a deeper market (i.e., larger open interest).

\section{Conclusions}

Futures exchanges in China started to launch nighttime trading sessions in 2013, and this move enabled its domestic traders to access the futures market around the clock. Because of the continuous trading hours, information from markets overseas can be 
Table 5 Behavior of volatility: pre- vs. post-nighttime trading (Shanghai Futures Exchange)

$\left|\varepsilon_{i t}\right|=\beta_{0 i}+\beta_{1 i} \mathrm{MON}_{t}+\beta_{2 i} \mathrm{DVOM}_{i t}+\beta_{3 i} \mathrm{DOl}_{i t}+\sum_{j=1}^{10} \rho_{i j}\left|\varepsilon_{i, t-j}\right|+\epsilon_{i t}$

\begin{tabular}{|c|c|c|c|c|c|c|c|c|c|c|c|c|}
\hline \multirow[b]{2}{*}{ Futures } & \multicolumn{6}{|l|}{ Pre } & \multicolumn{6}{|l|}{ Post } \\
\hline & $\overline{\text { Constant (t-stat) }}$ & MON (t-stat) & DVOM (t-stat) & DOI (t-stat) & $\operatorname{Lags}^{a}$ & $\begin{array}{l}\text { Adjusted } \\
R^{2}\end{array}$ & $\begin{array}{l}\text { Constant ( } t- \\
\text { stat) }\end{array}$ & MON (t-stat) & DVOM (t-stat) & DOI (t-stat) & Lags & $\begin{array}{l}\text { Adjustec } \\
R^{2}\end{array}$ \\
\hline Gold & $-0.0119(-0.599)$ & $\begin{array}{l}0.0014^{* *} \\
(2.004)\end{array}$ & $0.0551^{* * *}(3.483)$ & $-0.0403(-1.344)$ & 7 & 0.1515 & $\begin{array}{l}-0.0320 \\
(-0.653)\end{array}$ & $\begin{array}{l}0.0009 \\
(1.553)\end{array}$ & $\begin{array}{l}0.0364^{* * *} \\
(2.763)\end{array}$ & $0.0009(0.016)$ & 0 & 0.0711 \\
\hline Silver & $0.0529(0.365)$ & $0.0049(1.194)$ & $-0.0080(-0.103)$ & $-0.0397(-0.257)$ & 2 & 0.1406 & $\begin{array}{l}-0.0443 \\
(-1.015)\end{array}$ & $\begin{array}{l}0.0002 \\
(0.187)\end{array}$ & $\begin{array}{l}0.0461^{* * *} \\
(2.594)\end{array}$ & $0.0034(0.074)$ & 4 & 0.1143 \\
\hline $\begin{array}{l}\text { Copper } \\
\text { cathode }\end{array}$ & $0.0139(0.344)$ & $\begin{array}{l}0.0019^{* * *} \\
(3.308)\end{array}$ & $\begin{array}{l}-0.0176^{* * *} \\
(-2.974)\end{array}$ & $0.0061(0.147)$ & 9 & 0.1869 & $\begin{array}{l}-0.0506 \\
(-0.675)\end{array}$ & $\begin{array}{l}0.0012 \\
(1.556)\end{array}$ & $\begin{array}{l}0.1290^{* * *} \\
(6.560)\end{array}$ & $-0.0750(-0.938)$ & 2 & 0.2841 \\
\hline Aluminum & $\begin{array}{l}-0.0770^{* * *} \\
(-4.750)\end{array}$ & $\begin{array}{l}0.0008^{* *} \\
(2.422)\end{array}$ & $0.0302^{* * *}(4.616)$ & $0.0480^{* *}(2.364)$ & 8 & 0.3030 & $\begin{array}{l}-0.0185 \\
(-0.509)\end{array}$ & $\begin{array}{l}0.0006 \\
(1.611)\end{array}$ & $0.0224(1.593)$ & $-0.0011(-0.023)$ & 2 & 0.1439 \\
\hline Zinc & $-0.0597^{*}(-1.705)$ & $\begin{array}{l}0.0025^{* * *} \\
(3.808)\end{array}$ & $-0.0138(-1.107)$ & $0.0761^{* *}(1.999)$ & 8 & 0.1672 & $\begin{array}{l}-0.0392 \\
(-1.012)\end{array}$ & $\begin{array}{l}0.0005 \\
(0.657)\end{array}$ & $0.0277(1.556)$ & $0.0139(0.278)$ & 2 & 0.1384 \\
\hline Lead & $0.0060(1.386)$ & $\begin{array}{l}0.0016^{* *} \\
(2.576)\end{array}$ & $0.0234^{* * *}(5.499)$ & $\begin{array}{l}-0.0278^{* * *} \\
(-3.783)\end{array}$ & 3 & 0.2340 & $0.0323(1.264)$ & $\begin{array}{l}0.0000 \\
(0.027)\end{array}$ & $\begin{array}{l}0.0408^{* * *} \\
(6.676)\end{array}$ & $-0.0709^{* *}(-2.470)$ & 4 & 0.2764 \\
\hline Steel rebar & $-0.0084(-0.422)$ & $\begin{array}{l}0.0020^{* * *} \\
(4.498)\end{array}$ & $0.0987^{* * *}(11.146)$ & $\begin{array}{l}-0.0883^{* * *} \\
(-4.124)\end{array}$ & 8 & 0.2530 & $0.0672(1.074)$ & $\begin{array}{l}0.0015 \\
(1.403)\end{array}$ & $\begin{array}{l}0.1276^{* * *} \\
(5.945)\end{array}$ & $-0.1905^{* * *}(-2.848)$ & 0 & 0.3235 \\
\hline Natural rubber & $0.0019(0.101)$ & $\begin{array}{l}0.0022^{* * *} \\
(4.089)\end{array}$ & $\begin{array}{l}-0.0334^{* * *} \\
(-4.294)\end{array}$ & $0.0354^{*}(1.840)$ & 9 & 0.1040 & $0.0207(0.164)$ & $\begin{array}{l}0.0009 \\
(0.549)\end{array}$ & $\begin{array}{l}0.1761^{* * *} \\
(3.070)\end{array}$ & $-0.1815^{*}(-1.703)$ & 1 & 0.1562 \\
\hline
\end{tabular}

***, **, and * denote significance at $1 \%, 5 \%$, and $10 \%$, respectively

${ }^{a}$ Number of autoregressive terms significant at $5 \%$ level 
Table 6 Behavior of volatility: pre- vs. post-nighttime trading (Dalian Commodity Exchange)

\begin{tabular}{|c|c|c|c|c|c|c|c|c|c|c|c|c|}
\hline \multirow[b]{2}{*}{ Futures } & \multicolumn{6}{|l|}{ Pre } & \multicolumn{6}{|l|}{ Post } \\
\hline & Constant (t-stat) & MON (t-stat) & DVOM (t-stat) & DOI (t-stat) & Lags & Adjusted $R^{2}$ & Constant (t-stat) & MON (t-stat) & DVOM (t-stat) & DOI (t-stat) & Lags & Adjusted $R^{2}$ \\
\hline $\begin{array}{l}\text { RBD palm } \\
\text { olein }\end{array}$ & $-0.0145^{* *}(-2.099)$ & $0.0038^{* * *}(5.637)$ & $-0.0311^{* *}(-2.429)$ & $0.0472^{* * *}(2.749)$ & 9 & 0.2015 & $0.0951(1.438)$ & $0.0006(0.694)$ & $0.0853^{* * *}(5.452)$ & $-0.1753^{* *}(-2.535)$ & 2 & 0.1483 \\
\hline $\begin{array}{l}\text { Metallurgical } \\
\text { coke }\end{array}$ & $0.0148(0.790)$ & $0.0017^{* *}(2.486)$ & $0.0586^{* * *}(7.745)$ & $-0.0700^{* * *}(-3.163)$ & 5 & 0.1713 & $-0.0089(-0.496)$ & $-0.0001(-0.211)$ & $0.0785^{* * *}(10.376)$ & $-0.0664^{* * *}(-3.308)$ & 5 & 0.3935 \\
\hline $\begin{array}{l}\text { No. } 1 \\
\text { soybeans }\end{array}$ & $-0.0005(-0.024)$ & $0.0024^{* * *}(6.361)$ & $0.0373^{* * *}(4.323)$ & $-0.0354(-1.453)$ & 10 & 0.2063 & $0.0486(1.161)$ & $0.0005(0.648)$ & $0.0958^{* * *}(7.963)$ & $-0.1414^{* * *}(-2.928)$ & 2 & 0.3808 \\
\hline $\begin{array}{l}\text { Soybean } \\
\text { meal }\end{array}$ & $0.0122(0.364)$ & $0.0031^{* * *}(6.662)$ & $0.0182(1.382)$ & $-0.0279(-0.830)$ & 10 & 0.1242 & $0.2984^{* * *}(3.434)$ & $0.0026^{* *}(2.472)$ & $0.0959^{* * *}(5.703)$ & $-0.3872^{* * *}(-4.447)$ & 2 & 0.2841 \\
\hline $\begin{array}{l}\text { Crude } \\
\text { soybean oil }\end{array}$ & $0.0474(1.030)$ & $0.0034^{* * *}(5.602)$ & $-0.0011(-0.072)$ & $-0.0449(-0.917)$ & 8 & 0.1998 & $0.2916^{* * *}(2.789)$ & $0.0009(1.129)$ & $0.0722^{* * *}(4.231)$ & $-0.3565^{* * *}(-3.270)$ & 4 & 0.1508 \\
\hline Coking coal & $-0.0671^{*}(-1.913)$ & $0.0021^{* *}(2.245)$ & $0.0924^{* * *}(7.664)$ & $-0.0205(-0.533)$ & 1 & 0.2247 & $-0.0096(-0.345)$ & $-5.89 \mathrm{e}-06(-0.006)$ & $0.0785^{* * *}(6.202)$ & $-0.0644^{*}(-1.927)$ & 2 & 0.2887 \\
\hline Iron ore & $0.0627(1.312)$ & $0.0013(0.983)$ & $0.1018^{* * *}(7.358)$ & $-0.1570^{* * *}(-3.033)$ & 1 & 0.1838 & $0.0896(0.795)$ & $-0.0013(-0.875)$ & $0.1498^{* * *}(5.133)$ & $-0.2266^{*}(-1.755)$ & 1 & 0.1494 \\
\hline
\end{tabular}


Table 7 Behavior of volatility: pre- vs. post-nighttime trading (Zhengzhou Commodity Exchange)

\begin{tabular}{|c|c|c|c|c|c|c|c|c|c|c|c|c|}
\hline \multirow[b]{2}{*}{ Futures } & \multicolumn{6}{|l|}{ Pre } & \multicolumn{6}{|l|}{ Post } \\
\hline & Constant (t-stat) & MON (t-stat) & DVOM (t-stat) & DOI (t-stat) & Lags & Adjusted $R^{2}$ & Constant (t-stat) & MON (t-stat) & DVOM (t-stat) & DOI (t-stat) & Lags & Adjusted $R^{2}$ \\
\hline White sugar & $0.0352(0.897)$ & $0.0015^{* * *}(3.179)$ & $0.0613^{* * *}(3.673)$ & $-0.0938^{* *}(-2.314)$ & 7 & 0.1676 & $0.0595(0.921)$ & $0.0013(1.163)$ & $0.0986^{* * *}(4.794)$ & $-0.1516^{* *}(-2.227)$ & 0 & 0.1281 \\
\hline PTA & $0.0148(0.637)$ & $0.0028^{* * *}(4.720)$ & $0.0082(0.376)$ & $-0.0205(-0.581)$ & 7 & 0.1363 & $0.2208^{*}(1.927)$ & $0.0024(1.443)$ & $0.1291^{* * *}(4.055)$ & $-0.3397^{* * *}(-2.685)$ & 0 & 0.1013 \\
\hline No. 1 cotton & $0.0042(0.268)$ & $0.0013^{* * *}(3.894)$ & $0.0386^{* * *}(8.654)$ & $-0.0417^{* *}(-2.520)$ & 8 & 0.2952 & $0.0443(1.272)$ & $0.0015^{*}(1.878)$ & $0.0622^{* * *}(6.968)$ & $-0.1036^{* * *}(-2.676)$ & 2 & 0.2598 \\
\hline Rapeseed meal & $0.0743^{* *}(1.976)$ & $0.0020^{* *}(2.315)$ & $0.1022^{* * *}(7.406)$ & $-0.1712^{* * *}(-4.020)$ & 1 & 0.1161 & $0.0448(0.778)$ & $0.0014(1.082)$ & $0.1053^{* * *}(5.819)$ & $-0.1425^{* *}(-2.405)$ & 0 & 0.1016 \\
\hline Methanol & $-0.0022(-0.087)$ & $0.0018^{* * *}(2.921)$ & $0.0574^{* * *}(8.429)$ & $-0.0525^{*}(-1.885)$ & 3 & 0.2735 & $-0.0901(-1.437)$ & $0.0002(0.104)$ & $0.1417^{* * *}(4.118)$ & $-0.0402(-0.468)$ & 0 & 0.1811 \\
\hline Rapeseed oil & $0.0393(1.581)$ & $0.0024^{* * *}(5.077)$ & $0.0596^{* * *}(11.281)$ & $-0.0973^{* * *}(-3.623)$ & 8 & 0.2517 & $0.0355(0.248)$ & $0.0014(0.988)$ & $0.0610^{* * *}(2.770)$ & $-0.0931(-0.610)$ & 0 & 0.1179 \\
\hline Flat glass & $-0.0462(-1.586)$ & $0.0006(1.037)$ & $0.1090^{* * *}(12.136)$ & $-0.0568^{*}(-1.693)$ & 3 & 0.2651 & $-0.0308(-0.962)$ & $0.0021^{*}(1.673)$ & $0.1348^{* * *}(8.025)$ & $-0.0996^{* *}(-2.616)$ & 1 & 0.3977 \\
\hline Thermal coal & $0.0144(0.376)$ & $0.0003(0.277)$ & $0.0381^{* * *}(4.874)$ & $-0.0499(-1.237)$ & 2 & 0.2139 & $-0.0186(-0.588)$ & $0.0009(0.800)$ & $0.0430^{* * *}(4.811)$ & $-0.0202(-0.634)$ & 0 & 0.2044 \\
\hline
\end{tabular}


Table 8 Interaction between volatility, trading volume, and open interest (Shanghai Futures Exchange)

\begin{tabular}{|c|c|c|c|c|c|c|c|c|}
\hline & Constant (t-stat) & MON (t-stat) & DVOM (t-stat) & $\mathrm{NT} \times \mathrm{DVOM}$ (t-stat) & DOI (t-stat) & $\mathrm{NT} \times \mathrm{DOI}(t-$ stat $)$ & $\operatorname{Lags}^{a}$ & Adjusted $R^{2}$ \\
\hline Gold & $-0.0120(-0.620)$ & $0.0012^{* *}(2.325)$ & $0.0547^{* * *}(3.519)$ & $-0.0212(-1.054)$ & $-0.0393(-1.342)$ & $0.0198(0.987)$ & 6 & 0.1626 \\
\hline Silver & $-0.0245(-0.583)$ & $0.0007(0.752)$ & $0.0020(0.031)$ & $0.0429(0.660)$ & $0.0306(0.447)$ & $-0.0463(-0.701)$ & 3 & 0.1242 \\
\hline Copper cathode & $0.0142(0.379)$ & $0.0017^{* * *}(3.552)$ & $-0.0175^{* * *}(-2.951)$ & $0.1572^{* * *}(7.226)$ & $0.0058(0.153)$ & $-0.1585^{* * *}(-7.322)$ & 9 & 0.2143 \\
\hline Aluminum & $-0.0723^{* * *}(-4.716)$ & $0.0008^{* * *}(2.637)$ & $0.0303^{* * *}(4.655)$ & $-0.0074(-0.504)$ & $0.0433^{* *}(2.233)$ & $0.0069(0.469)$ & 7 & 0.3028 \\
\hline Zinc & $-0.0552^{*}(-1.960)$ & $0.0021^{* * *}(3.931)$ & $-0.0135(-1.073)$ & $0.0393^{*}(1.901)$ & $0.0714^{* *}(2.265)$ & $-0.0408^{* *}(-1.970)$ & 8 & 0.1971 \\
\hline Lead & $0.0086^{*}(1.770)$ & $0.0009^{* *}(2.038)$ & $0.0239 * * *(5.315)$ & $0.0129^{*}(1.732)$ & $-0.0305^{* * *}(-3.827)$ & $-0.0132^{*}(-1.812)$ & 3 & 0.2392 \\
\hline Steel rebar & $-0.0020(-0.102)$ & $0.0020^{* * *}(4.741)$ & $0.0975^{* * *}(11.059)$ & $0.0369(1.417)$ & $-0.0933^{* * *}(-4.313)$ & $-0.0362(-1.406)$ & 7 & 0.2666 \\
\hline Natural rubber & $0.0018(0.096)$ & $0.0021^{* * *}(4.204)$ & $-0.0331^{* * *}(-4.233)$ & $0.1952^{* * *}(3.364)$ & $0.0355^{*}(1.852)$ & $-0.1951^{* * *}(-3.362)$ & 7 & 0.1021 \\
\hline
\end{tabular}

****** and * denote significance at $1 \%, 5 \%$, and $10 \%$ levels, respectively

aNumber of autoregressive terms significant at $5 \%$ level 
Table 9 Interaction between volatility, trading volume, and open interest (Dalian Commodity Exchange)

\begin{tabular}{|c|c|c|c|c|c|c|c|c|}
\hline & Constant (t-stat) & MON (t-stat) & DVOM (t-stat) & NT × DVOM (t-stat) & DOI (t-stat) & $\mathrm{NT} \times \mathrm{DOI}(t-$ stat $)$ & Lags & Adjusted $R^{2}$ \\
\hline RBD palm olein & $-0.0120^{*}(-1.706)$ & $0.0033^{* * *}(5.839)$ & $-0.0309^{* *}(-2.417)$ & $0.1051^{* * *}(5.343)$ & $0.0450^{* * *}(2.618)$ & $-0.1057^{* * *}(-5.387)$ & 8 & 0.1955 \\
\hline Metallurgical coke & $0.0094(0.596)$ & $0.0014^{* * *}(2.664)$ & $0.0584^{* * *}(8.063)$ & $0.0173^{*}(1.751)$ & $-0.0642^{* * *}(-3.447)$ & $-0.0182^{*}(-1.861)$ & 4 & 0.2190 \\
\hline No. 1 soybeans & $0.0028(0.140)$ & $0.0023^{* * *}(6.396)$ & $0.0375^{* * *}(4.354)$ & $0.0584^{* * *}(3.783)$ & $-0.0388^{*}(-1.658)$ & $-0.0589^{* * *}(-3.846)$ & 10 & 0.2134 \\
\hline Soybean meal & $0.0150(0.463)$ & $0.0030^{* * *}(6.816)$ & $0.0184(1.396)$ & $0.0675^{* * *}(3.315)$ & $-0.0309(-0.947)$ & $-0.0683^{* * *}(-3.371)$ & 8 & 0.1288 \\
\hline Crude soybean oil & $0.0584(1.362)$ & $0.0031^{* * *}(5.827)$ & $-0.0007(-0.044)$ & $0.0646^{* * *}(3.215)$ & $-0.0562(-1.218)$ & $-0.0650^{* * *}(-3.241)$ & 6 & 0.1927 \\
\hline Coking coal & $-0.0410^{*}(-1.863)$ & $0.0014^{*}(1.904)$ & $0.0924^{* * *}(7.769)$ & $-0.0183(-1.026)$ & $-0.0464^{*}(-1.799)$ & $0.0174(0.977)$ & 1 & 0.2447 \\
\hline Iron ore & $0.0717(1.497)$ & $0.0002(0.200)$ & $0.1065^{* * *}(7.661)$ & $0.0395(1.231)$ & $-0.1693^{* * *}(-3.278)$ & $-0.0372(-1.169)$ & 2 & 0.1929 \\
\hline
\end{tabular}


Table 10 Interaction between volatility, trading volume, and open interest (Zhengzhou Commodity Exchange)

\begin{tabular}{|c|c|c|c|c|c|c|c|c|}
\hline & Constant (t-stat) & MON (t-stat) & DVOM (t-stat) & NT $\times$ DVOM (t-stat) & DOI (t-stat) & NT $\times$ DOI (t-stat) & Lags & Adjusted $R^{2}$ \\
\hline White sugar & $0.0431(1.203)$ & $0.0015^{* * *}(3.332)$ & $0.0618^{* * *}(3.694)$ & $0.0391(1.547)$ & $-0.1020^{* * *}(-2.741)$ & $-0.0394(-1.560)$ & 6 & 0.1627 \\
\hline PTA & $0.0198(0.873)$ & $0.0028^{* * *}(5.024)$ & $0.0098(0.459)$ & $0.1113^{* *}(2.472)$ & $-0.0265(-0.771)$ & $-0.1109^{* *}(-2.468)$ & 5 & 0.1244 \\
\hline No. 1 cotton & $0.0057(0.383)$ & $0.0013^{* * *}(4.212)$ & $0.0387^{* * *}(8.726)$ & $0.0266^{* * *}(2.901)$ & $-0.0433^{* * *}(-2.737)$ & $-0.0269^{* * *}(-2.954)$ & 7 & 0.2946 \\
\hline Rapeseed meal & $0.0587^{* *}(1.988)$ & $0.0017^{* *}(2.346)$ & $0.1005^{* * *}(7.459)$ & $1.46 \mathrm{E}-05(0.001)$ & $-0.1531^{* * *}(-4.473)$ & $8.65 \mathrm{E}-06(0.000)$ & 0 & 0.1203 \\
\hline Methanol & $-0.0160(-0.633)$ & $0.0014^{* *}(2.256)$ & $0.0526^{* * *}(7.443)$ & $0.1017^{* * *}(3.867)$ & $-0.0318(-1.122)$ & $-0.0989^{* * *}(-3.763)$ & 2 & 0.2594 \\
\hline Rapeseed oil & $0.0399(1.621)$ & $0.0023^{* * *}(5.134)$ & $0.0596^{* * *}(11.272)$ & $0.0115(0.545)$ & $-0.0978^{* * *}(-3.677)$ & $-0.0116(-0.555)$ & 5 & 0.2479 \\
\hline Flat glass & $-0.0400^{*}(-1.868)$ & $0.0009(1.595)$ & $0.1090^{* * *}(12.323)$ & $0.0221(1.329)$ & $-0.0634^{* *}(-2.471)$ & $-0.0220(-1.322)$ & 2 & 0.2897 \\
\hline Thermal coal & $0.0074(0.260)$ & $0.0005(0.690)$ & $0.0375^{* * *}(4.946)$ & $0.0096(0.845)$ & $-0.0415(-1.352)$ & $-0.0097(-0.875)$ & 0 & 0.2244 \\
\hline
\end{tabular}


incorporated into the futures price in China at night. Traders in China no longer need to wait until the next-day trading session to react to new information and therefore can better manage their risk.

In this study, we use daily price and trading activity data from China's commodity futures with the recently added nighttime trading hours to investigate the impact of these additional sessions. The descriptive statistics, such as the mean, variance, skewness, and kurtosis during the pre- and post-nighttime trading sub-sample periods indicate that the returns have become more symmetric while the downside risk and the fat tail in returns have been effectively mitigated. The results indicate that a more even flow of information has been incorporated into the futures prices after nighttime trading.

We also use a regression analysis to test whether the volatility behavior of the sample futures changed significantly after the launching of nighttime trading. Results from a sub-sample analysis suggest that several futures have a negative volatility-trading volume relationship and a positive volatility-open interest relationship during the prenighttime trading period. The signs of these coefficients are either reversed or become insignificant, a change that is consistent with the theoretical patterns observed in developed country financial markets such as those in the USA, implying that new information has been incorporated into the futures prices. Additionally, the autocorrelation in volatility is much weaker during the post-nighttime trading period. One interesting finding is that almost all the sample commodity futures' volatility was subject to a positive Monday effect during the pre-nighttime trading period, while such effects were eliminated after the launching of nighttime trading.

A full sample analysis with interaction terms added to the regression reveals more information about the effect of nighttime trading. We find that after nighttime trading sessions were introduced, the relationship between volatility and trading volume became more positive, while that between volatility and open interest (a proxy for market depth) became more negative.

These findings confirm our hypothesis that the accessibility of the futures market at night has effectively enhanced the price efficiency of commodity futures in China. The behavior of volatility as well as its interactions with trading activities was improved and become more consistent with the observed pattern in developed markets, as documented in the literature. In summary, this study presents evidence that this recent policy change in China's futures market is a steady and effective step to achieve its goal of enhancing price-setting power in key commodities on world markets and provides a good example for other developing countries.

\section{Endnotes}

${ }^{1}$ Futures Industry Magazine (March 2015). Retrieved from https://fimag.fia.org/sites/ default/files/content_attachments/2014\%20FIA\%20Annual\%20Volume\%20Survey\%20\% E2\%80\%93\%20Charts\%20and\%20Tables.pdf

${ }^{2}$ For example, bitumen, hot rolled coils, nickel, and tin on SHFE are excluded for lack of pre-night trading data. Soybean no. 2 on the DCE is also excluded because of thin trading.

${ }^{3}$ The Jarque-Bera test statistics are not presented in the table but are available upon request. 
Competing interests

The paper does not receive external funding from outside sources and there is no conflict of interest among authors to any agency.

\section{Authors' contributions}

Each author contributes equally to the paper. All authors read and approved the final manuscript.

\section{Acknowledgements}

We thank Jot Yau for the helpful comments.

\section{Author details}

${ }^{1}$ College of Business Administration \& Office of International Services and Program, University of Missouri-St. Louis, One University Blvd, St. Louis, MO 63121, USA. ${ }^{2}$ College of Business Administration, University of Missouri-St. Louis, One University Blvd, St. Louis, MO 63121, USA. ${ }^{3}$ Department of Finance, Martha and Spencer Love School of Business, Elon University, Elon, NC 27244, USA.

Received: 24 February 2016 Accepted: 18 March 2016

Published online: 20 April 2016

\section{References}

Admati A, Pfleidere P (1988) A theory of intraday patterns: volume and price variability. Rev Financ Stud 1:3-40 Bessembinder H, Seguin PJ (1992) Futures-trading activity and stock price volatility. J Financ 47:2015-2034 Bessembinder H, Seguin PJ (1993) Price volatility, trading volume, and market depth: evidence from futures markets. J Financ Quant Anal 28:21-39

Clark PK (1973) A subordinated stochastic process model with finite variance for speculative prices. Econometrica 41:135-155 Daigler RT, Wiley MK (1999) The impact of trader type on the futures volatility-volume relation. J Financ 54:2297-2316 Downing C, Zhang F (2004) Trading activity and price volatility in the municipal bond market. J Financ 59:899-931 Epps TW, Epps ML (1976) The stochastic dependence of security price changes and transaction volumes: implications for the mixture-of-distributions hypothesis. Econometrica 44:305-321

Eun CS, Shim S (1989) International transmission of stock market movements. J Financ Quant Anal 24:241-256 Foster AJ (1995) Volume-volatility relationships for crude oil futures markets. J Futur Mark 15:929-951

Fung H-G, Patterson GA (2001) Volatility, global information, and market conditions: a study in futures markets. J Futur Mark 21:173-196

Fung H-G, Leung WK, Xu XE (2001) Information role of U.S. futures trading in a global financial market. J Futur Mark 21: 1071-1090

Ghosh A, Saidi R, Johnson KH (1999) Who moves the Asia-Pacific stock markets: US or Japan? Empirical evidence based on the theory of cointegration. Financ Rev 34:159-170

Jones CM, Kaul G, Lipson ML (1994) Transactions, volume and volatility. Rev Financ Stud 7:631-651

Kao EH, Fung HG (2012) Intraday trading activities and volatility in round-the-clock futures markets. Int Rev Econ Financ 21:195-209

Karpoff JM (1987) The relation between price changes and trading volume: a survey. J Financ Quant Anal 22:109-126 Kim O, Verrecchia RE (1994) Market liquidity and volume around earnings announcements. J Account Econ 17:41-67 Kyle AS (1985) Continuous auctions and insider trading. Econometrics 53:1315-1335

Pliska SR, Shalen CT (1991) The effects of regulations on trading activity and return volatility in futures markets. J Futur Mark 11:135-152

Schwert GW (1990) Stock volatility and the crash of '87. Rev Financ Stud 3:77-102

Tauchen G, Pitt M (1983) The price variability-volume relationship on speculative markets. Econometrica 51:485-505 Wang GHK, Yau J (2000) Trading volume, bid-ask spread, and price volatility in futures markets. J Futur Mark 20:943-970 Xu XE, Fung H-G (2005) Cross-market linkages between U.S. and Japanese precious metals futures trading. J Int Financ Mark Inst Money 15:107-124

\section{Submit your manuscript to a SpringerOpen ${ }^{\circ}$ journal and benefit from:}

- Convenient online submission

$\checkmark$ Rigorous peer review

- Immediate publication on acceptance

- Open access: articles freely available online

- High visibility within the field

- Retaining the copyright to your article 